\title{
ANP - SWOT APPROACH TO MINIMIZE ENVIRONMENTAL IMPACTS DUE MINING ACTIVITIES
}

\author{
Anna Ostrega* \\ AGH University of Science and Technology \\ Faculty of Mining and Geoengineering \\ Cracow, Poland \\ E-mail: ostrega@agh.edu.pl \\ Fabio De Felice \\ University of Cassino \\ Faculty of Engineering \\ Cassino, FR, ITALY \\ E-mail: defelice@unicas.it \\ Antonella Petrillo \\ University of Cassino \\ Faculty of Engineering \\ Cassino, FR, ITALY \\ E-mail: a.petrillo@unicas.it
}

\begin{abstract}
The debate surrounding sustainable development in the mining industry is a drawn-out one, which has long gained considerable attention from a wide range of parties. Minimizing adverse environmental impacts is an important goal for all industries keen on contributing to sustainable development. The realization of sustainable development requires the use of different disciplinary approaches to the impact assessment of development proposals. This paper examines sustainable development in the corporate mining context, and provides some guidelines for mining companies seeking to operate more sustainably. Since mining processes have the potential to impact a diverse group of environmental entities, and are of interest to a wide range of stakeholder groups, there is ample opportunity for the industry to operate more sustainably. The present study proposes an integrated and hybrid approach based on SWOT Analysis and Analytic Network Process (ANP). The analysis prescribes policy recommendations both for the government and industry which, if adopted, could facilitate improving of environmental performance developing a framework for sustainable development indicators for the mining industry. In fact the combined use of ANP method and SWOT analysis is a promising approach in supporting strategic decision-making processes.
\end{abstract}

Keywords: ANP, SWOT Analysis, mining, integrated impact assessment.

\section{Introduction}

Every industry, in addition to generic environmental complications, faces industry specific challenges that require careful planning, tactical investment, and strategic management to overcome. In the case of mining, the environmental problems resulting from operations are well known (Water discharge, Dewatering, Smelting, Dust pollution, Transportation, Minerals depletion) particularly because the industry attracts considerable public attention with its ongoing need to obtain planning permission to take land out of other uses and to extract minerals, as well with its nuisance effects, such as noise, dust and

\footnotetext{
${ }^{*}$ Corresponding author
} 
traffic. To contribute to sustainable development, a mine must minimize environmental impacts throughout its lifecycle, from exploration, through extraction and processing, to mine closure and land reclamation. Moreover in view of the environmental problems that persist in the mining industry, there is a need to implement cleaner technologies on a number of fronts, and a mine can pursue one of two strategies to achieve improvement.

There must be a scientific and suitable method for measuring the degree of sustainable development of mineral resources well and truly. But most of current evaluation theories and methods of sustainable development are concerned with sustainability at global and national levels (Bond, Curran, Kirkpatrick, Lee, \& Francis, 2001; Bossel, 1999; Lo'pez-Ridaura, Masera, \& Astier, 2002; Malkina- Pykh, 2002; Ronchi, Federico, \& Musmeci, 2002).

There is no universal and perfect approach for strategic sustainable planning in the mining field so in this study the strengths, weaknesses, opportunities, and threats (SWOT) approach in combination with analytic hierarchy/network process (AHP/ANP) to assess the effect of environmental, economic, and social factors relating to a typical mining industry were used.

AHP/ANP originally developed by Saaty (1980) has been studied extensively and used in many applications in the last 20 years it is common known. The wide ANP applicability is due to its simplicity, ease of use, and great flexibility there is something missing in this sentence. The SWOT-AHP/ANP allows to define proper decision process in a hierarchical structure of factors, evaluate factors in pairs, and quantify the relative importance of each factor to the adoption decision. Preference data from selected opinion leaders involved in mining industry was utilized. The aim of this paper is to identify principal factors controlling the degree of sustainable development of mineral resources of mining and the development of a useful methodology based on Analytic Network Process and SWOT Analysis for conducting integrated impact assessment.

The paper is divided in the following sections: second section "Outline for methodological application: Research structure"; third section "SWOT-ANP Model: An Example"; last section "Conclusions and Results".

\section{Outline for methodological application: Research structure}

In an effort to promote cleaner production and environmental management tools in the mining industry, certain countries - both industrialized and industrializing - have revamped sector of? specific environmental regulations. To respond to these increasing environmental regulations, mining companies have adopted environmental management practices.

The SWOT approach involves systematic thinking and comprehensive diagnosis of factors relating to a new product, technology, management, or planning. The use of this method gives rise to some important advantages and disadvantages. The advantages, for instance, may include the idea that this method is very simple and everybody can use it without having advanced knowledge or external technical support. The disadvantages refer to a variety of shortcomings regarding this method such as its simplistic, static and subjective character.

Then one of the main limitations of this approach is that the importance of each factor in decision-making cannot be measured quantitatively. As such it is difficult to assess which factors influences the strategic decision most (Pesonen et al., 2000). If used in combination with Analytic Hierarchy or Network? Process, SWOT approach can provide a quantitative measure of importance of each factor on decisionmaking (Kurttila et al., 2000; Saaty and Vargas, 2001; Ananda and Herath, 2003). ANP enables decision makers to assign a relative priority to each factor through pair-wise comparison.

Our research involves several stages, includes identification of key stakeholders involved in the decision problem, classification of critical factors influencing the decision, and evaluation of the factors using SWOT-ANP framework. SWOT-ANP framework is shown on the Figure 1. 




Figure 1: SWOT-ANP framework

In particular with:

1. SWOT analysis we identified the strengths, weaknesses, opportunities, and threats that an organization faces. The strengths and weaknesses are identified by an internal environment appraisal, while the opportunities and threats are identified by an external environment appraisal;

2. ANP enables decision-makers to quantify intangible factors.

In our opinion the integrated SWOT-ANP approach is preferred as the intensities of strengths, weaknesses, opportunities, and threats can be quantified, and therefore can lead to a more realistic and effective decision than stand-alone SWOT or ANP. For implementing the proposed SWOT-ANP approach, we selected ten participants and categorized them in two groups: Academic Expert (AE) and Governmental Expert (GE). In figure 2 research methodological approach is shown.

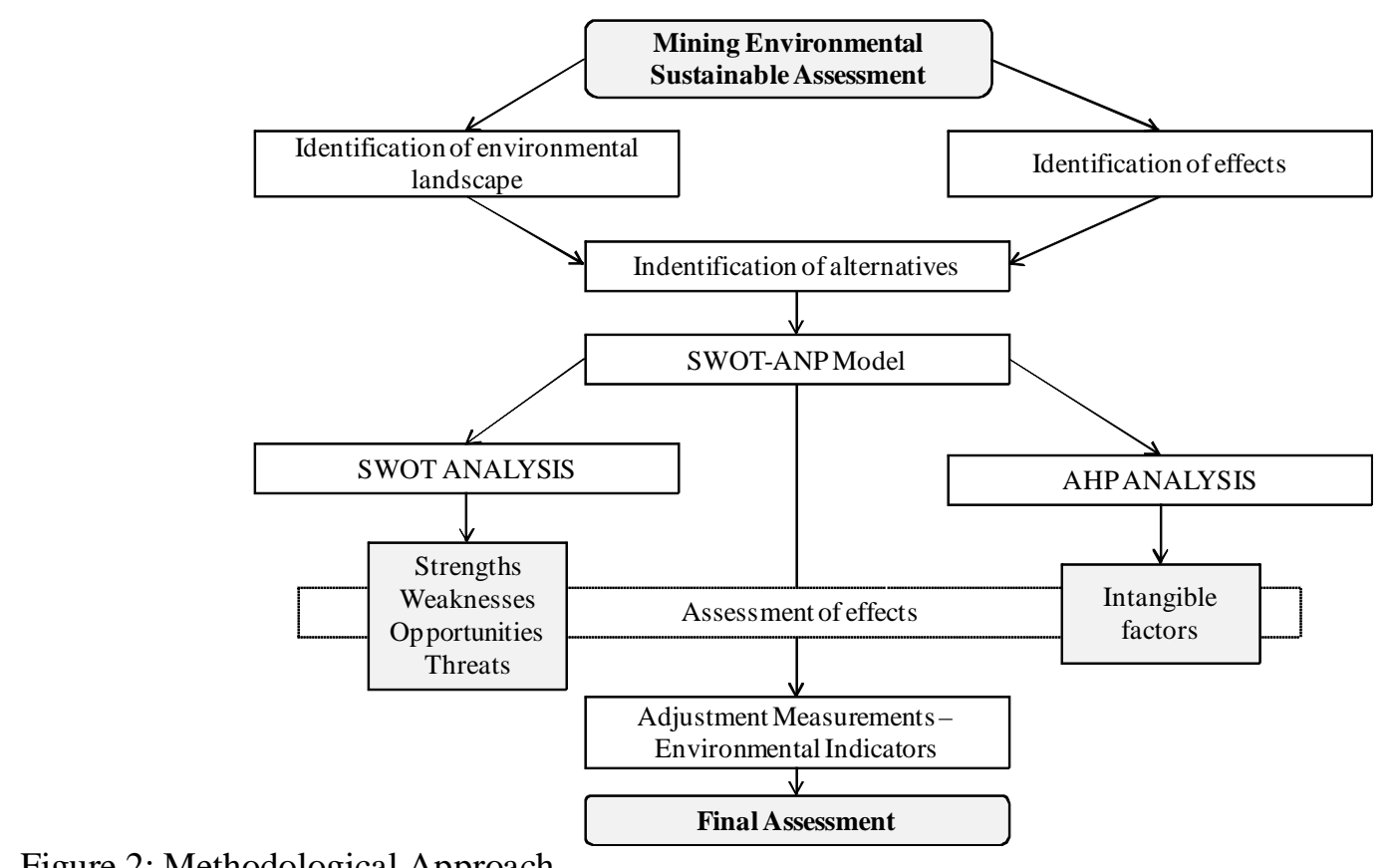

Figure 2: Methodological Approach 


\section{ANP - SWOT Model: An Example}

Extractive operations invariably lead to a variety of environmental impacts, including depletion of nonrenewable resources, transforming of the landscape and above-average threats for health and safety of workers and citizens. These and the other issues have prompted the mining industry to engage in the sustainability debate and start devising strategies for responding to the challenge of sustainable development. Legislation, combined with stakeholders' pressure, has acted as one of the main driving forces for the interest of the industry in sustainability. However, the industry is now also starting to recognize that corporate sustainability can bring business benefits through (Azapagic, 2004):

- Lower labor and health costs by providing safe and healthy working environment;

- Cost savings due to cleaner production methods and innovation;

- Easier access to lenders, insurers, preferential loans and insurance rates;

- Lower closure and post-closure costs;

- Best practice influence on regulation;

- Higher value for goodwill on the balance sheet and

- Market advantages created by a socially responsible approach to business.

As we said the aim of the SWOT - ANP model is to prescribes policy recommendations both for the government and industry which, if adopted, could facilitate improved environmental performance. Following in table 1 we identified and classified the critical SWOT indicators for a typical mining industry (Nikolaous and Evangelinos, 2010).

In particular we examined aggregate annual reports and environmental reports - who's report? Some mining company?. These reports were analyzed according to the GOAL "Degree of sustainable development of mining resources".

The evaluation of environmental reports is related to the content analysis technique and SWOT analysis (see Table 1).

Table 1. Criteria and Sub Criteria.

\begin{tabular}{|c|c|c|}
\hline \multicolumn{3}{|c|}{$\begin{array}{c}\text { GOAL } \\
\text { Degree of sustainable development of mining resources }\end{array}$} \\
\hline \multirow{2}{*}{$\begin{array}{c}\text { Criteria - SWOT } \\
\text { GROUP }\end{array}$} & \multicolumn{2}{|c|}{ Sub Criteria - SWOT FACTORS } \\
\hline & Factor & Description \\
\hline \multirow{3}{*}{$\begin{array}{l}\text { Strengths } \\
\quad(\mathrm{S})\end{array}$} & S1. Cost reduction & $\begin{array}{l}\text { It is generally recognized that environmental } \\
\text { management practices assist in reducing the } \\
\text { operating costs of companies mainly in the long } \\
\text { run. }\end{array}$ \\
\hline & S2. Productivity improvement & $\begin{array}{l}\text { The Mining Industry considers that well } \\
\text { implemented environmental management } \\
\text { practices reduce the use of material resources } \\
\text { and, as a consequence, they have better } \\
\text { productivity improvements. }\end{array}$ \\
\hline & S3. Innovation development & $\begin{array}{l}\text { The majority of Mining Industry invests in new } \\
\text { technology as well as in research and } \\
\text { development (R\&D) environmental programs } \\
\text { such as technologies to manage air pollution or } \\
\text { dust pollution. }\end{array}$ \\
\hline $\begin{array}{l}\text { Weaknesses } \\
\qquad(\mathrm{W})\end{array}$ & W1. Lack of founds & $\begin{array}{l}\text { The Mining Industry states that environmental } \\
\text { management practices need high levels of } \\
\text { funding. Specifically, some companies spend } \\
\text { over } 20 \% \text { of their total revenue in adopting } \\
\text { environmental } \quad \text { measures, employee }\end{array}$ \\
\hline
\end{tabular}




\begin{tabular}{|c|c|c|}
\hline & & $\begin{array}{l}\text { environmental training and appropriate } \\
\text { equipment. }\end{array}$ \\
\hline & W2. Bureaucratic requirements & $\begin{array}{l}\text { The majority of Mining Industry claim that the } \\
\text { implementation of such practices as well as of } \\
\text { holistic environmental management systems } \\
\text { entail a variety of bureaucratic requirements not } \\
\text { only for the staff of companies' environmental } \\
\text { departments but also for the overall staff of } \\
\text { those companies. }\end{array}$ \\
\hline & $\begin{array}{l}\text { W3. Lack of management and staff } \\
\text { involvement }\end{array}$ & $\begin{array}{l}\text { In general the staff of the Mining Industry has } \\
\text { low qualifications, trust, interest and unclear } \\
\text { expectations about supporting environmental } \\
\text { practices. }\end{array}$ \\
\hline \multirow{4}{*}{$\begin{array}{l}\text { Opportunities } \\
\text { (O) }\end{array}$} & $\begin{array}{l}\text { O1. New markets, consumers and } \\
\text { competitive advantage }\end{array}$ & $\begin{array}{l}\text { In general the environmentally responsible } \\
\text { attitude of mining companies can provide a } \\
\text { competitive advantage due to the fact that they } \\
\text { meet the environmental needs of consumers. }\end{array}$ \\
\hline & O2. Enhanced financing opportunities & $\begin{array}{l}\text { Today, there are several financial opportunities } \\
\text { for Mining Industries, which adopt or are willing } \\
\text { to adopt environmental practices. }\end{array}$ \\
\hline & O3. Exports & $\begin{array}{l}\text { It is necessary for Mining Industries to } \\
\text { implement globally recognized and holistic } \\
\text { environmental management practices in order to } \\
\text { have easy access to foreign markets. }\end{array}$ \\
\hline & O4. Public awareness & $\begin{array}{l}\text { The main reason for such Mining Industries to } \\
\text { implement environmental management practices } \\
\text { is pressure from the general public for a cleaner } \\
\text { environment. }\end{array}$ \\
\hline \multirow{3}{*}{$\begin{array}{l}\text { Treats } \\
(\mathrm{T})\end{array}$} & T1. Additional funds & $\begin{array}{l}\text { Mining Industries consider that the concept of } \\
\text { continuous improvement of environmental } \\
\text { performance may require additional funding, } \\
\text { which will impact on their annual budget. }\end{array}$ \\
\hline & T2. Severe future legal requirements & $\begin{array}{l}\text { The environmental reports of the companies } \\
\text { implicated state that the present and future } \\
\text { environmental regulation frameworks are very } \\
\text { strict. }\end{array}$ \\
\hline & $\begin{array}{l}\text { T3. Lack of broad environmentally } \\
\text { friendly clientele }\end{array}$ & $\begin{array}{l}\text { The current low level of consumer demand for } \\
\text { environmentally friendly products has caused } \\
\text { concern to the senior management of companies } \\
\text { that have heavily invested in improving } \\
\text { environmental quality. }\end{array}$ \\
\hline
\end{tabular}

On the basis of the more structured conception of the decision situation, four alternative strategies were created for the holding as follows:

- A1. Mineral extraction that is improve production system such as engineering service and environmental impacts;

- A2. Mineral processing that is improve mineral processing activities on site such as dewatering and smelting process;

- A3. Waste handling and remediation that is improve waste rock dump, tailing, effluents and remediation techniques;

- A4. Water discharge that is improve use of mining industrial water.

Here below (Figure 3) is ANP-SWOT proposed model. 


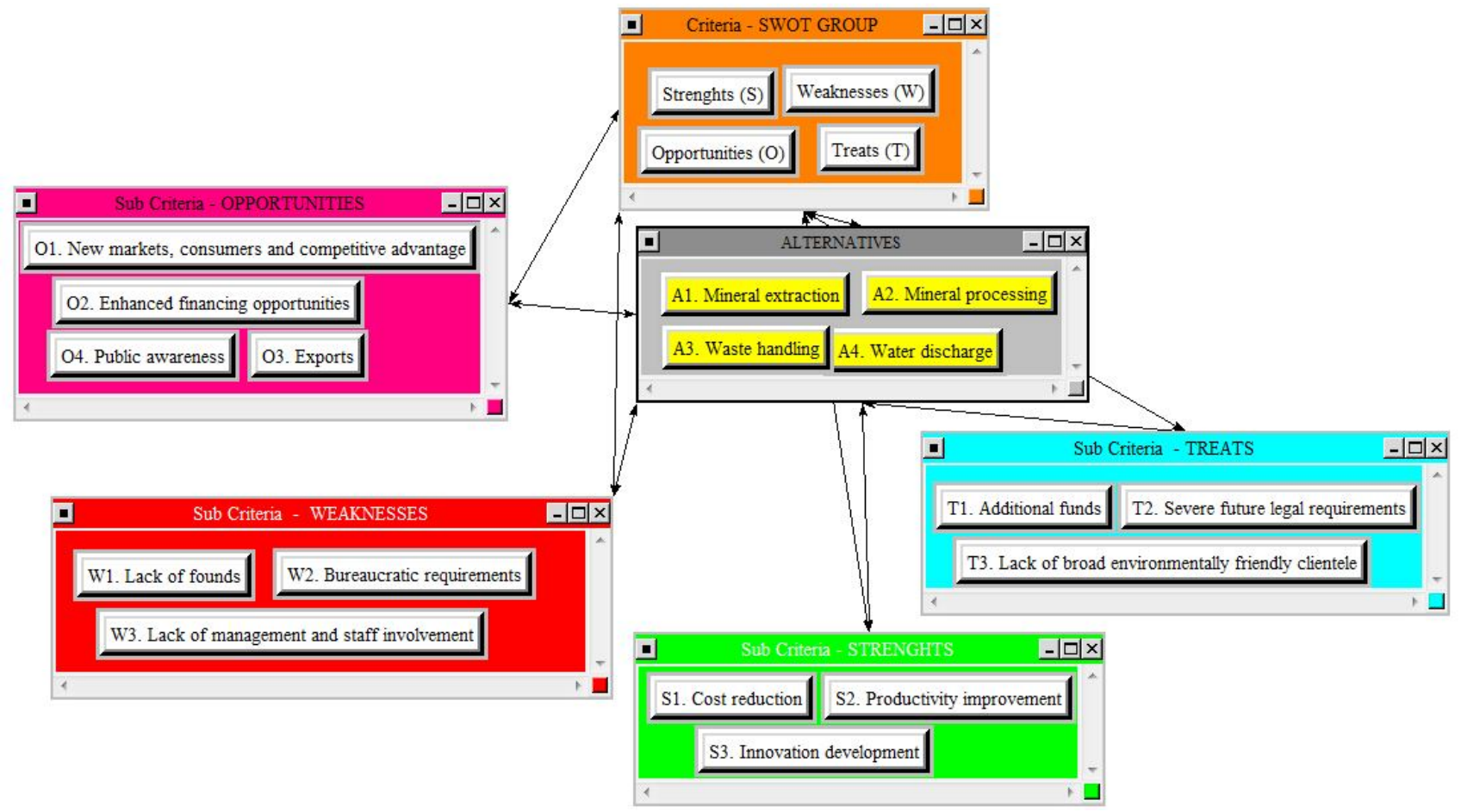

Figure 3: ANP - SWOT Proposed Model

This model allow us to define critical factor among alternatives. In Table 2 we show a possible scenario.

Table 2. Example of results.

\begin{tabular}{|l|l|l|}
\hline \multicolumn{1}{|c|}{ Alternatives } & Critical Factor & \\
\cline { 1 - 2 } A1. Mineral extraction & 0.256 & \\
\hline A2. Mineral processing & 0.455 & Critical factor \\
\hline A3. Waste handling & 0.170 & \\
\cline { 1 - 2 } A4. Water discharge & 0.118 & \\
\cline { 1 - 2 } & \multicolumn{2}{|c|}{}
\end{tabular}

At this point to conclude analysis we propose a specific framework for sustainability indicators. The purpose of sustainability indicators for industry is to help measure a company's economic, environmental and social performance and to provide information on how it contributes to sustainable development. Therefore, the indicators must be able to translate both internally-relevant and externally-important sustainability issues into the representative measures of performance.

Table 3. Framework for sustainability indicators.

\begin{tabular}{|l|l|l|c|}
\hline Parameter & \multicolumn{1}{|c|}{ Indicator } & \multicolumn{1}{c|}{ Description } & Unit \\
\hline Extraction & $\begin{array}{l}\text { Breakdown of the amount of } \\
\text { each saleable primary resource }\end{array}$ & $\begin{array}{l}\text { Amounts of primary resources } \\
\text { that need to be extracted to obtain } \\
\text { mineral products and through that } \\
\text { the rate of extraction and }\end{array}$ & t/yr \\
\hline
\end{tabular}




\begin{tabular}{|c|c|c|c|}
\hline & & depletion of natural resources. & \\
\hline & $\begin{array}{l}\text { Percentage of each resource } \\
\text { extracted relative to the total } \\
\text { amount of the permitted reserves } \\
\text { of that resource. }\end{array}$ & $\begin{array}{l}\text { Rate of depletion of the permitted } \\
\text { reserves also indicating how long } \\
\text { a company can rely on the } \\
\text { existing (permitted) reserves }\end{array}$ & $\% / y r$ \\
\hline \multirow[t]{2}{*}{ Process } & $\begin{array}{l}\text { Percentage of renewable energy } \\
\text { used relative to total energy } \\
\text { consumption. }\end{array}$ & $\begin{array}{l}\text { Ratio of renewable and non- } \\
\text { renewable energy used and } \\
\text { through that company's } \\
\text { commitment to using more } \\
\text { sustainable sources of energy. }\end{array}$ & $\%$ \\
\hline & $\begin{array}{l}\text { Emissions of greenhouse gases } \\
\left(\mathrm{CO}_{2}, \mathrm{CH}_{4}, \mathrm{~N}_{2} \mathrm{O}, \mathrm{HFCs} \text {, PFCs, }\right. \\
\left.\mathrm{SF}_{6}\right) \text {, breakdown by substance. }\end{array}$ & $\begin{array}{l}\text { Emissions of greenhouse gases; } \\
\text { enables calculation of } \\
\text { contribution to global warming. }\end{array}$ & $\mathrm{t} / \mathrm{yr}$ \\
\hline \multirow[b]{3}{*}{ Waste } & $\begin{array}{l}\text { Total waste extracted (non- } \\
\text { saleable material, including the } \\
\text { overburden). }\end{array}$ & $\begin{array}{l}\text { The amount of waste that needs to } \\
\text { be removed to obtain mineral } \\
\text { products. }\end{array}$ & $\mathrm{t} / \mathrm{yr}$ \\
\hline & $\begin{array}{l}\text { Percentage of waste chemicals } \\
\text { (processed or unprocessed) used } \\
\text { from both internal and external } \\
\text { sources. }\end{array}$ & $\begin{array}{l}\text { The level of recycling of } \\
\text { chemicals. }\end{array}$ & $\%$ \\
\hline & $\begin{array}{l}\text { Total hazardous } \text { and non- } \\
\text { hazardous solid waste and } \\
\text { breakdown by type and } \\
\text { description of disposal methods. }\end{array}$ & $\begin{array}{l}\text { The amount of solid waste } \\
\text { generated in the extraction and } \\
\text { production activities (e.g. tailings, } \\
\text { waste rocks, hazardous waste, } \\
\text { office waste etc.) and the disposal } \\
\text { methods, including reuse, } \\
\text { recycling, incineration and } \\
\text { disposal methods for hazardous } \\
\text { waste. }\end{array}$ & $\mathrm{t} / \mathrm{yr}$ \\
\hline \multirow{3}{*}{ Water } & $\begin{array}{l}\text { Total water use (mains and } \\
\text { surface/underground water). }\end{array}$ & $\begin{array}{l}\text { Amount of water resources used } \\
\text { for the production of mineral } \\
\text { resources. }\end{array}$ & $\mathrm{m}^{3} / \mathrm{yr}$ \\
\hline & $\begin{array}{l}\text { Percentage of water recycled } \\
\text { and reused (e.g. cooling, waste } \\
\text { and rain water) relative to the } \\
\text { total water withdrawn from } \\
\text { source. }\end{array}$ & $\begin{array}{l}\text { Water use in the minerals } \\
\text { operations relative to water } \\
\text { withdrawn from the environment } \\
\text { (from surface sources or } \\
\text { groundwater). }\end{array}$ & $\%$ \\
\hline & $\begin{array}{l}\text { Total volume of water } \\
\text { discharged into waterways. }\end{array}$ & $\begin{array}{l}\text { The amount of water returned to } \\
\text { the environment. }\end{array}$ & $\mathrm{m}^{3} / \mathrm{yr}$ \\
\hline
\end{tabular}

\section{Conclusions and Results}

Sustainable development is becoming increasingly more important for the mining industry. From this point of view it is important develop a specific methodological approach. In particular connecting ANP method with SWOT analysis yields analytical priorities for the factors included in SWOT analysis and makes them commensurable. In addition, decision alternatives can be evaluated with respect to each SWOT factor. In this way, SWOT analysis provides the basic frame within which to perform analyses of decision situations. ANP methods, in turn, assist in carrying out SWOT more analytically and in elaborating the results of the analyses so that alternative strategic decisions can be prioritized also with respect to the entire SWOT. 
Then this method supports the identification of the most significant sustainability indicators affecting the mining industry. In comparison to the stand-alone SWOT and ANP, the integrated SWOT-ANP approach makes it possible not only to identify and classify various indicators, but also to quantify their relative significance. Finally the proposed approach helps decision makers to provide accurate judgments on the significance of various indicators representing the prospects. Further work will develop a more details framework of indicators.

\section{REFERENCES}

Azapagic, A. (2004). Developing a framework for sustainable development indicators for the mining and minerals industry. Journal of Cleaner Production 12, 639-662.

Ananda, J., Herath, G., 2003. The use of Analytic Hierarchy Process to incorporate stakeholder preferences into regional forest planning. Forest Policy and Economics 5, 13-26.

Bond, R., Curran, J., Kirkpatrick, C., Lee, N., \& Francis, P. (2001). Integrated impact assessment for sustainable development: A case study approach. World Development, 29(6), 1011-1024.

Bossel, H. (1999). Indicators for sustainable development: Theory, method, applications. Winnipeg: International Institute for Sustainable Development.

Ho W (2008) Integrated analytic hierarchy process and its applications - a literature review. Eur J Oper Res 186(1):211-228. doi:10.1016/j.ejor.2007.01.004.

Lo'pez-Ridaura, S., Masera, O., \& Astier, M. (2002). Evaluating the sustainability of complex socioenvironmental systems. The MESMIS framework. Ecological Indicators, 2(1/2), 135-148.

Kurttila, M., Pesonen, M., Kangas, J., Kajanus, M., 2000. Utilizing the analytic hierarchy process AHP in SWOT analysis - a hybrid method and its application to a forest-certification case. Forest Policy and Economics 1, 41-52.m

Malkina-Pykh, I. G. (2002). Integrated assessment models and response function models: Pros and cons for sustainable development indices design. Ecological Indicators, 2(1/2), 93-108.

Nikolaou I.E., Evangelinos K.I., A SWOT analysis of environmental management practices in Greek Mining and Mineral Industry. International Journal of Resources Policy 35 (2010) 226-234.

Pesonen, M., Kurttila, M., Kangas, J., Kajanus, M., Heinonen, P., 2000. Assessing the priorities using A_WOT? among resource management strategies at the Finish Forest and Park Service. Forest Science 47 (4), 534-541.

Ronchi, E., Federico, A., \& Musmeci, F. (2002). A system oriented integrated indicator for sustainable development in Italy. Ecological Indicators, 2(1/2), 197-210.

Saaty T.L. (1980) The analytic hierarchy process. McGraw-Hill, New York.

Saaty, T.L., Vargas, L.G., 2001. Models, Methods, Concepts and Applications of the Analytic Hierarchy Process. Kluwer Academic Publishers, Boston, MA. 